\title{
Acute hepatitis $E$ in a renal transplantation recipient: a case report
}

This article was published in the following Dove Press journal: International Medical Case Reports Journal

\author{
Mitsutoshi Shindo' \\ Hiroaki Takemae ${ }^{2}$ \\ Takafumi Kubo ${ }^{2}$ \\ Masatsugu Soeno ${ }^{2}$ \\ Tetsuo Ando ${ }^{2}$ \\ Yoshiyuki Morishita' \\ 'Division of Nephrology, First \\ Department of Integrated Medicine, \\ Saitama Medical Center, Jichi \\ Medical University, Saitama, Japan; \\ ${ }^{2}$ Department of Dialysis and \\ Transplant Surgery, Hidaka Hospital, \\ Gunma, Japan
}

\begin{abstract}
Hepatitis E is caused by infection with the hepatitis E virus (HEV). HEV is transmitted orally via HEV-contaminated food or drink. Hepatitis E usually shows mild symptoms and is self-limiting in the general population; however, it may progress to chronic hepatitis in immunosuppressed patients such as recipients of organ transplantation. However, a few cases of acute hepatitis $\mathrm{E}$ have been reported in organ transplantation recipients. We herein report a case of acute hepatitis $\mathrm{E}$ in a 31-year-old male renal transplant recipient. The patient underwent renal transplantation 2 years ago, and his postoperative course was uneventful without rejection. After complaining of general fatigue and low-grade fever for 1 week, he was referred to and admitted to our hospital. Careful interview revealed that he ate undercooked pork 10 weeks prior. Blood analysis revealed liver dysfunction but was serologically negative for hepatitis A, $\mathrm{B}$ and $\mathrm{C}$ virus, cytomegalovirus infection and collagen diseases. Immunoglobulin $\mathrm{A}$ antibody against hepatitis E virus (HEV-IgA) was also negative at that point. After 2 weeks of admission, HEV-IgA and HEV-RNA were measured again as hepatitis E could not be ruled out due to history of ingestion of undercooked meat that may have been contaminated with HEV. At that time, HEV-IgA and HEV-RNA (genotype 3) were positive. Thus, an acute hepatitis E was diagnosed. His liver function gradually improved to within the normal range, and HEV-IgA and HEV-RNA were negative at 11 weeks after admission. In conclusion, we describe here a case of acute hepatitis $\mathrm{E}$ in a renal transplant recipient. Careful interview regarding the possibility of ingestion of HEV-contaminated food and repeated measurements of HEV-IgA were helpful in finalizing a diagnosis.
\end{abstract}

Keywords: hepatitis E virus, anti-HEV IgA, recipient, renal transplantation, zoonosis

\section{Introduction}

Hepatitis E is caused by infection with the hepatitis E virus (HEV), which is a singlestranded, non-enveloped, RNA icosahedral virus. ${ }^{1} \mathrm{HEV}$ is most commonly transmitted orally through ingesting food or drink that is contaminated with $\mathrm{HEV}^{2,3}$ Hepatitis E has been reported to usually cause mild symptoms such as low-grade fever, appetite loss and mild jaundice and is self-limiting in the general population. ${ }^{1}$ However, it may develop into chronic hepatitis in immunosuppressed patients such as recipients of organ transplantation. ${ }^{4}$ In the study by Kamar et $a 1,{ }^{5} 66 \%$ of hepatitis E patients who were also organ transplantation recipients progressed to chronic hepatitis and $10 \%$ these chronic hepatitis E patients progressed to liver cirrhosis.

However, a few cases of acute hepatitis $E$ have been reported in organ transplantation recipients. We herein report a case of acute hepatitis $\mathrm{E}$ in a renal transplant recipient.
Correspondence: Yoshiyuki Morishita Division of Nephrology, First Department of Integrated Medicine, Saitama Medical Center, Jichi Medical University, I-847 Amanuma-cho, Omiya-ku, Saitama-city, Saitama 330-8503, Japan

Tel +8I 486472 III

Fax: +8I 48647683 I

Email ymori@jichi.ac.jp 


\section{Case report}

The patient was a 31-year-old man who underwent renal transplantation 2 years ago. The donor was his mother. Their $\mathrm{ABO}$ blood type was compatible, and antibodies against donorspecific human leukocyte antigen were negative in the recipient as determined by complement-dependent cytotoxicity, flow cytometry-based crossmatch and panel reactive antibody. His postoperative course was uneventful without rejection, and his immunosuppressive regimen consisted of $3.5 \mathrm{mg} /$ day tacrolimus, $1000 \mathrm{mg} /$ day mycophenolate mofetil and $0.5 \mathrm{mg} /$ day everolimus. The patient's liver function was normal. He was referred to our hospital after complaining of general fatigue and low-grade fever starting 1 week before presentation. Careful interview revealed that he ate undercooked pork 10 weeks prior. A low-grade fever was observed, but jaundice and abdominal pain were not. Blood examination revealed liver dysfunction. He was admitted to our hospital for further examination and treatment for liver dysfunction. Written informed consent to publication was obtained from the patient.

The laboratory data upon admission are shown in Table 1. Blood examination showed liver dysfunction but was negative for antigens and antibodies for hepatitis A, B and C virus, cytomegalovirus (CMV) infection and collagen diseases (Table 1).
Immunoglobulin A antibody against hepatitis E virus (HEV-IgA) was also negative at that point (Table 1). Notably, markers of liver damage were upregulated over time (Figure 1). Because we knew he ate undercooked pork 10 weeks prior, we thought that the possibility of hepatitis E could not be ruled out as the cause of his liver disease. Therefore, we measured HEV-IgA again and also measured HEV-IgM and HEV-RNA 2 weeks after admission. At that time, both HEV-IgA and HEV-IgM were positive as well as genotype 3 HEV-RNA (4.3 log copy/ $\mathrm{mL}$, cutoff value: $<2.0 \log$ copy $/ \mathrm{mL}$; Figure 1). Therefore, acute hepatitis $\mathrm{E}$ was diagnosed. The administration of ursodeoxycholic acid, monoammonium glycyrrhizinate, glycine, aminoacetic acid and L-cysteine hydrochloride hydrate was started for liver protection. No specific antiviral agent against HEV was used. His liver function gradually improved to within the normal range, and HEV-IgA and HEV-RNA were once again negative at 11 weeks after admission (Figure 1). During this episode, the administration of immunosuppressive agents was continued without deterioration in renal function of the transplanted kidney.

\section{Discussion}

We have described a case of acute hepatitis $\mathrm{E}$ in a renal transplant recipient. Four genotypes of HEV have been reported. ${ }^{6}$

Table I Laboratory findings at initial presentation

\begin{tabular}{|c|c|c|c|c|c|}
\hline \multicolumn{2}{|c|}{$\begin{array}{l}\text { Complete blood count and blood } \\
\text { chemistry }\end{array}$} & \multicolumn{2}{|l|}{ Immunological analysis } & \multicolumn{2}{|c|}{ Urinary analysis } \\
\hline WBC & $4630 / \mu \mathrm{L}$ & $\mathrm{HBs}-\mathrm{Ag}$ & - & $\mathrm{pH}$ & 5.5 \\
\hline RBC & $496 \times 10^{3} / \mu \mathrm{L}$ & $\mathrm{HBs}-\mathrm{Ab}$ & - & Protein & - \\
\hline Hematocrit & $43.5 \%$ & $\mathrm{HBc}-\mathrm{Ab}$ & - & Occult blood & - \\
\hline Hemoglobin & $14.2 \mathrm{~g} / \mathrm{dL}$ & HAV-lgG & - & WBC & - \\
\hline Platelets & $17.1 \times 10^{4} / \mu \mathrm{L}$ & HAV-IgM & - & & \\
\hline Total protein & $7.7 \mathrm{~g} / \mathrm{dL}$ & $\mathrm{HCV}-\mathrm{Ab}$ & - & & \\
\hline Albumin & $4.5 \mathrm{~g} / \mathrm{dL}$ & HEV-IgA & - & & \\
\hline Total bilirubin & $0.9 \mathrm{mg} / \mathrm{dL}$ & $\operatorname{CMV}(\mathrm{ClO} / \mathrm{II})$ & $0 / 0$ & & \\
\hline AST & I56 IU/L & CMV-IgG & + & & \\
\hline ALT & $300 \mathrm{IU} / \mathrm{L}$ & CMV-IgM & - & & \\
\hline ALP & $4|4| \mathrm{IU} / \mathrm{L}$ & Antinuclear antibody & 40-fold & & \\
\hline$\gamma$-GTP & $126 \mathrm{IU} / \mathrm{L}$ & Anti-mitochondrial M2 antibody & - & & \\
\hline BUN & $19.9 \mathrm{mg} / \mathrm{dL}$ & & & & \\
\hline Creatinine & $1.46 \mathrm{mg} / \mathrm{dL}$ & & & & \\
\hline Uric Acid & $6.7 \mathrm{mg} / \mathrm{dL}$ & & & & \\
\hline Sodium & $137 \mathrm{mmol} / \mathrm{L}$ & & & & \\
\hline Potassium & $4.3 \mathrm{mmol} / \mathrm{L}$ & & & & \\
\hline Chloride & $104 \mathrm{mmol} / \mathrm{L}$ & & & & \\
\hline Calcium & $9.9 \mathrm{mg} / \mathrm{dL}$ & & & & \\
\hline Phosphorus & $3.4 \mathrm{mg} / \mathrm{dL}$ & & & & \\
\hline CRP & $<0.05 \mathrm{mg} / \mathrm{dL}$ & & & & \\
\hline
\end{tabular}

Abbreviations: WBC, white blood cells; HBs-Ag, hepatitis B virus surface antigen; RBC, red blood cells; HBs-Ab, antibody against hepatitis $B$ virus surface proteins; $\mathrm{HBc}-\mathrm{Ab}$, antibody against hepatitis $B$ virus core proteins; $H B s-A g$, hepatitis $B$ virus surface-antigen; $H A V$-lgG, immunoglobulin $G$ antibody against hepatitis $A$ virus; $H A V$ IgM, immunoglobulin $M$ antibody against hepatitis $A$ virus; HCV-Ab, antibody against hepatitis $C$ virus; HEV-lgA, immunoglobulin $A$ antibody against hepatitis $E$ virus; CMV, cytomegalovirus; AST, aspartate aminotransferase; CMV-lgG, immunoglobulin G antibody against cytomegalovirus; ALT, alanine aminotransferase; CMV-lgM, immunoglobulin $M$ antibody against cytomegalovirus; ALP, alkaline phosphatase; $\gamma$-GTP, $\gamma$-glutamyl transpeptidase; BUN, blood urea nitrogen; CRP, C-reactive protein. 


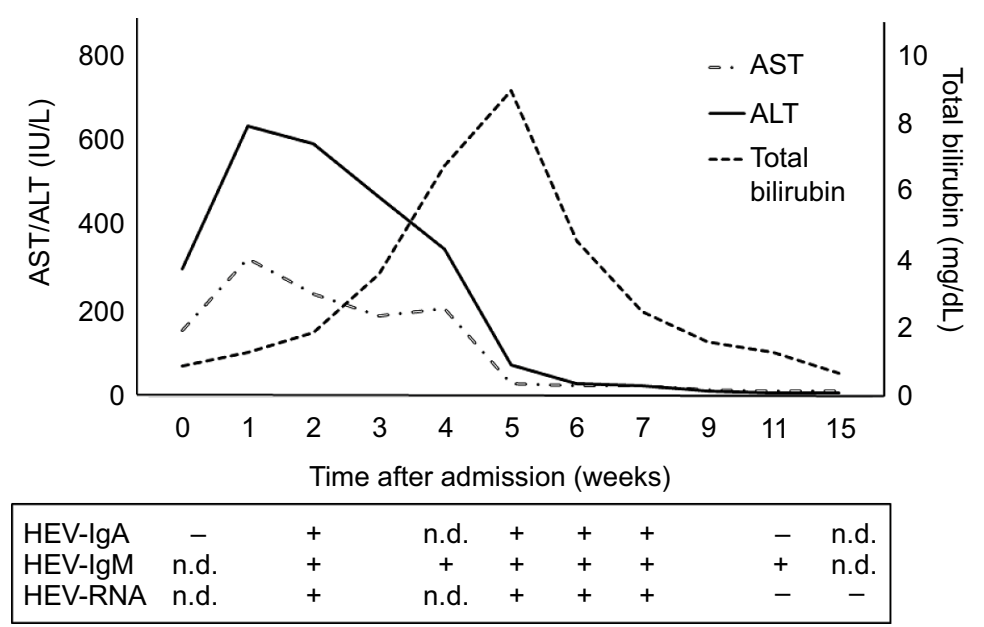

Figure I Patient's clinical course.

Abbreviations: AST, aspartate aminotransferase; ALT, alanine aminotransferase; HEV-lgA, immunoglobulin A antibody against hepatitis E virus; HEV-lgM, immunoglobulin $M$ antibody against hepatitis $E$ virus; HEV, hepatitis E virus; n.d., not determined.

Genotypes 1 and 2 of HEV can only be transmitted to humans via waterborne and fecal-oral transmission. ${ }^{6}$ Genotypes 3 and 4 of $\mathrm{HEV}$ are transmitted via zoonotic infections from pigs, wild boar, deer and other animals and humans. ${ }^{6}$ Humans are therefore commonly infected with HEV by ingesting meat or water contaminated with $\mathrm{HEV}^{7}$ In addition, blood transfusion and allograft transplantation reportedly increase the risk of transmission of HEV because screening for HEV is not well established in blood and organ donation. ${ }^{8,9}$ In the present case, the patient had a recent history of ingestion of undercooked meat but not of blood transfusion. Additionally, his postoperative course was uneventful without liver dysfunction during the 2 years after renal transplantation. Therefore, HEV in this patient may be caused by ingestion of HEV-contaminated meat.

Previously, hepatitis E has been diagnosed based on the presence of HEV-IgM and HEV-RNA. ${ }^{10}$ However, recently HEV-IgA has been used as a first screening examination to detect the acute phase of HEV infection because HEV-IgA is superior to HEV-IgM in terms of sensitivity and specificity. ${ }^{11}$ HEV-IgA has been reported to be positive when symptoms appear, and liver enzymes increase in the general population. ${ }^{11}$ However, in this patient, HEV-IgA was negative when symptoms first appeared and liver enzymes increased. Notably, HEV-IgA showed a delayed positive response at 5 weeks later. Immunosuppression in this patient may contribute to the delayed production of HEV-IgA. It may therefore be better to measure HEV-IgA repeatedly with HEV-RNA to diagnose hepatitis $\mathrm{E}$ in immunosuppressed patients. A previous study reported that hepatitis E progressed to chronic hepatitis in $66 \%$ of organ transplantation recipients and all chronic hepatitis $\mathrm{E}$ infections were caused by HEV genotype $3 .{ }^{10}$ In this case, HEV (genotype 3 ) infection did not progress to chronic hepatitis despite the patient taking immunosuppressive agents. The low titer of HEV-RNA of $4.3 \log$ copy $/ \mathrm{mL}$ (cutoff value: $<2.0 \log$ copy $/ \mathrm{mL}$ ) may have contributed to the HEV infection not progressing to a chronic infection. Further studies are required to investigate both the mechanism of progression of HEV infection to chronic hepatitis and the optimal testing and treatment of HEV in immunosuppressed patients.

\section{Conclusion}

We have described a case of acute hepatitis $\mathrm{E}$ in a renal transplant recipient. Careful interview regarding the possibility of consumption of $\mathrm{HEV}$-contaminated food and repeated measurements of HEV-IgA were helpful in finalizing a diagnosis. Undercooked meat may be recommended to be excluded from menu in immunosuppressed patients such as recipients of organ transplantation.

\section{Acknowledgment}

We thank Simon Teteris, PhD, from the Edanz Group for editing the English in this manuscript.

\section{Author contributions}

All authors contributed toward data analysis, drafting and revising the paper and agree to be accountable for all aspects of the work.

\section{Disclosure}

The authors report no conflicts of interest in this work. 


\section{References}

1. Dalton HR, Bendall R, Ijaz S, Banks M. Hepatitis E: an emerging infection in developed countries. Lancet Infect Dis. 2008;8(11):698-709.

2. Tei S, Kitajima N, Takahashi K, Mishiro S. Zoonotic transmission of hepatitis E virus from deer to human beings. Lancet. 2003;3(62):371-373.

3. Matsuda H, Okada K, Takahashi K, Mishiro S. Severe hepatitis E virus infection after ingestion of uncooked liver from a wild boar. $J$ Infect Dis. 2003;188:944.

4. Kamar N, Kamar N, Selves J, et al. Hepatitis E virus and chronic hepatitis in organ-transplant recipients. $N$ Engl J Med. 2008;358:811-817.

5. Kamar N, Garrouste C, Haagsma EB, et al. Factors associated with chronic hepatitis in patients with hepatitis $\mathrm{E}$ virus infection who have received solid organ transplants. Gastroenterology. 2011;140:1481-1489.
6. Okamoto H. Genetic variability and evolution of hepatitis E virus. Virus Res. 2007;127:216-228.

7. Kamar N, Bendall R, Legrand-Abravanel F, et al. Hepatitis E. Lancet. 2012;379(9835):2477-2488.

8. Hewitt PE, Ijaz S, Brailsford SR, et al. Hepatitis E virus in blood components: a prevalence and transmission study in southeast England. Lancet. 2014;384(9956):1766-1773.

9. Gallian P, Lhomme S, Piquet $Y$, et al. Hepatitis E virus infections in blood donors, France. Emerg Infect Dis. 2014;20:1914-1917.

10. Kamar N, Dalton HR, Abravanel F, Izopet J. Hepatitis E virus infection. Clin Microbiol Rev. 2014;27:116-138.

11. Takahashi M, Kusakai S, Mizuo H, et al. Simultaneous detection of immunoglobulin $\mathrm{A}(\operatorname{IgA})$ and $\operatorname{IgM}$ antibodies against hepatitis $\mathrm{E}$ virus (HEV) is highly specific for diagnosis of acute HEV infection. $J$ Clin Microbiol. 2005;43:49-56.
International Medical Case Reports Journal

\section{Publish your work in this journal}

The International Medical Case Reports Journal is an international, peer-reviewed open-access journal publishing original case reports from all medical specialties. Previously unpublished medical posters are also accepted relating to any area of clinical or preclinical science. Submissions should not normally exceed 2,000 words or

\section{Dovepress}

4 published pages including figures, diagrams and references. The manuscript management system is completely online and includes a very quick and fair peer-review system, which is all easy to use. Visit $\mathrm{http}: / /$ www.dovepress.com/testimonials.php to read real quotes from published authors.

Submit your manuscript here: https:/www.dovepress.com/international-medical-case-reports-journal-journal 